\title{
SEDIAAN BIJI BARRINGTONIA ASIATICA: AKTIVITAS PADA HAMA KUBIS CROCIDOLOMIA PAVONANA DI LABORATORIUM DAN KEEFEKTIFAN DI LAPANGAN
}

\author{
Edy Syahputra ${ }^{1}$
}

\begin{abstract}
Preparation of Barringtonia asiatica: insecticidal activity against Crocidolomia pavonana on laboratory and effectiveness on field. The objectives of this study were to evaluate the insecticidal and anti-oviposition activity of ethanol seed extract of Barringtonia asiatica against Crocidolomia pavonana in the laboratory, and to determine the effectiveness of a simple preparation of $B$. asiatica seeds in supressing oviposition and population of $C$. pavonana in the field. The mortality bioassays were conducted by a leaf-feeding method. Anti-oviposition activity was assessed by a choice-test in the nursery. The results showed that the ethanol seed extract of $B$. asiatica possessed strong insecticidal activity against $C$. pavonana larvae with $\mathrm{LC}_{50}$ of $0.14 \%$. The extract at concentrations of $0.14-1.00 \%$ reduced oviposition by $C$. pavonana female as much as $65.7-95.6 \%$. B. asiatica seeds ground in water for 5 seconds and then immersed for 1 hour at a concentration of $50 \mathrm{~g} \mathrm{l}^{-1}$ yielded a simple preparation which was active against $C$. pavoana larvae. Such simple preparation at a concentration of $75 \mathrm{~g}$ $1^{-1}$ sprayed on cabbage crop effectively suppressed population of $C$. pavonana larvae in the field.
\end{abstract}

Key words: Barringtonia asiatica, Crocidolomia pavonana, botanical insecticide

\section{PENDAHULUAN}

Sampai saat ini pengendalian yang umum digunakan oleh petani sayuran suku kubis (Brassicaceae) ialah penyemprotan insektisida sintetik dengan frekuensi aplikasi yang tinggi. Petani kubis di Jawa Barat dalam mengendalikan hama yang menyerang tanaman kubis menyemprotkan insektisida sintetik rata-rata lebih dari 10 kali dalam satu musim tanam (Rauf et al., 2005). Selain masih kurangnya minat petani untuk melakukan cara-cara pengendalian non-kimia, pemilihan cara pengendalian tersebut dilakukan karena insektisida sintetik dianggap lebih efektif dan efisien dalam penggunaannya. Namun, pengaplikasian insektisida sintetik yang intensif dan berlebihan menyebabkan dampak negatif terhadap serangga hama tersebut dan terhadap lingkungan sekitarnya serta bagi pengguna insektisida.

Beranjak dari permasalahan penggunaan insektisida sintetik dan meningkatnya kesadaran akan kelestarian lingkungan, kini terus dicari cara pengendalian yang lebih aman, salah satunya adalah pemanfaatan tanaman sebagai insektisida botani. Penggunaan insektisida botani memiliki beberapa keunggulan, di antaranya mudah terurai di lingkungan dan relatif aman terhadap parasitoid (Dono \& Prijono, 1998; Schmutterer, 1997). Selain itu, pada daerah tertentu insektisida botani dapat diproduksi dan digunakan langsung oleh petani sehingga diharapkan dapat mengurangi biaya produksi pertanian.

Beberapa jenis tumbuhan Meliaceae dan Annonaceae telah diketahui memiliki aktivitas insektisida. Akhir-akhir ini banyak dilaporkan jenis tumbuhan dari famili lainnya yang aktivitas insektisidanya baru dilaporkan secara terbatas. Syahputra et al. (2004) melaporkan bahwa beberapa spesies tumbuhan dari Clusiaceae, Lecythidaceae, dan Sapindaceae aktif terhadap serangga. Informasi aktivitas insektisida sediaan tanaman dari tiga famili tersebut lebih sedikit dibandingkan dengan informasi aktivitas insektisida sediaan tanaman Meliaceae atau Annonaceae. Khusus famili Lecythidaceae, beberapa spesiesnya dilaporkan memiliki aktivitas biologi terhadap hewan. Selain tumbuhannya aktif sebagai racun ikan, ekstrak kulit batang Barringtonia lanceolata dan B. sarcostachys aktif terhadap larva Crocidolomia pavonana

${ }^{1}$ Bidang Minat Proteksi, Fakultas Pertanian, Universitas Tanjungpura,

Jl. A. Yani, Pontianak, 78124. E-mail: e_sitorus_2000@yahoo.com 
(Syahputra et al., 2001). Sediaan buah B. asiatica (jawa: keben) bersifat menghambat makan kumbang Attagenus piceus, sedangkan sediaan kulit batang B. racemosa selain bersifat menghambat makan pada kumbang $A$. piceus juga bersifat insektisida terhadap kutu daun Toxoptera aurantii (Grainge \& Ahmed, 1988). Hingga kini belum dilaporkan senyawa aktif yang bertanggung jawab terhadap aktivitas tersebut.

Aktivitas ekstrak Barringtonia spp. di atas baru dilaporkan untuk pengujian di laboratorium. Keefektifan ekstrak tumbuhan tersebut di lapangan dan teknik penyiapan untuk penggunaan langsung di tingkat petani belum pernah dilaporkan. Penelitian ini bertujuan mengevaluasi aktivitas insektisida dan penghambatan peneluran ekstrak biji $B$. asiatica terhadap serangga $C$. pavonana dan cara-cara penyiapan sediaan sederhananya di laboratorium. Selain itu, dalam penelitian ini akan dievaluasi keefektifan sediaan tersebut dalam menekan peneluran dan populasi hama C. pavonana di lapangan.

\section{METODE PENELITIAN}

Tumbuhan Sumber Ekstrak dan Serangga Uji. Bahan tumbuhan yang digunakan sebagai sumber ekstrak adalah biji $B$. asiatica yang diperoleh dari Sengkubang, Kecamatan Sungai Kunyit, Kabupaten Pontianak, Kalimantan Barat pada bulan Januari 2007. Biji tersebut diblender hingga menjadi serbuk dan diayak menggunakan pengayak kasa bermata $1 \mathrm{~mm}$. Serbuk ayakan ditimbang untuk keperluan ekstraksi.

Serangga uji yang digunakan adalah C. pavonana yang merupakan hama penting tanaman Brassicaceae. Serangga uji diperbanyak dengan pakan daun brokoli di Laboratorium Hama dan Penyakit Tumbuhan, Jurusan Agronomi, Fakultas Pertanian, Universitas Tanjungpura, Pontianak.

Ekstraksi Bahan Tumbuhan. Ekstraksi biji tumbuhan dilakukan dengan dua cara, yaitu ekstraksi dengan pelarut organik dan ekstraksi sederhana. Ekstraksi dengan pelarut organik dilakukan menggunakan etanol dengan metode perendaman. Serbuk biji $B$. asiatica direndam dengan etanol (1:10) selama 24 jam. Larutan ekstrak disaring dengan kertas saring, kemudian diuapkan dengan rotary evaporator (suhu $55-60^{\circ} \mathrm{C}$; tekanan 580 $600 \mathrm{mmHg}$ ). Ekstrak yang dihasilkan siap digunakan untuk pengujian.

Ekstraksi sederhana dilakukan dengan menggunakan air sebagai pelarut. Ekstraksi ini merupakan pendekatan untuk mencari cara penyiapan sediaan untuk penggunaan langsung oleh petani di lapangan. Sebagai bahan aktif sediaan digunakan serbuk biji $B$. asiatica. Pelarut yang digunakan ialah air yang mengandung etanol dan pengemulsi deterjen (Rinso) dengan konsentrasi masig-masing $1 \%(\mathrm{v} / \mathrm{v})$ dan $0,1 \%$ (w/v) (selanjutnya disebut pelarut sederhana). Sediaan disiapkan dengan dua cara, yaitu (1) serbuk biji B. asiatica direbus selama 1 jam dalam pelarut sederhana, (2) pemblenderan selama 15 detik + perendaman serbuk biji selama 1 jam dalam pelarut sederhana. Sebagai pembanding digunakan ekstrak etanol biji $B$. asiatica serta serbuk dan ekstrak biji nimba (Azadirachta indica). Cara penyiapan serbuk dan ekstrak biji nimba dilakukan seperti cara penyiapan serbuk dan ekstrak biji B. asiatica.

\section{Metode Pengujian}

Aktivitas Insektisida. Pengujian bertujuan mengevaluasi aktivitas insektisida ekstrak biji $B$. asiatica terhadap larva instar II $C$. pavonana. Pengujian aktivitas insektisida dilakukan dengan metode residu pada daun. Cara pengujian dilakukan seperti yang diuraikan Syahputra et al. (2004). Ekstrak etanol diuji pada lima taraf konsentrasi yang ditentukan melalui uji pendahuluan. Ekstrak diuji pada konsentrasi 0,05\%; $0,07 \% ; 0,1 \% ; 0,14 \%$ dan $0,2 \%$. Pemberian pakan daun brokoli perlakuan dilakukan selama 48 jam, selanjutnya larva diberi pakan daun tanpa perlakuan hingga mencapai instar IV. Jumlah larva yang mati dicatat setiap 24 jam. Hubungan antara konsentrasi ekstrak dengan tingkat kematian serangga uji diolah dengan analisis probit (SAS Institute, 1990).

Pengujian sediaan ekstrak sederhana dilakukan pada konsentrasi $50 \mathrm{~g} \mathrm{l}^{-1}$ dan $100 \mathrm{~g} \mathrm{l}^{-1}$. Pemilihan konsentrasi ini berdasarkan batas kelayakan penggunaan bahan tanaman langsung di lapangan. Sediaan sederhana rebusan serbuk disiapkan dengan cara merebus serbuk di dalam pelarut selama 1 jam di atas nyala api bunsen sambil diaduk. Selanjutnya campuran bahan rebusan didinginkan dan setelah dingin disaring dengan saringan kain. Suspensi hasil saringan siap digunakan untuk pengujian. Sediaan sederhana serbuk blender-rendam disiapkan dengan cara menimbang serbuk dengan bobot tertentu kemudian diblender dalam pelarut sederhana selama 15 detik. Campuran bahan tersebut dibiarkan terendam pelarut sederhana selama 1 jam. Setelah perendaman, campuran bahan tersebut disaring dan suspensi hasil saringan siap digunakan untuk pengujian. Cara penyiapan sediaan sederhana pembanding dari serbuk biji $A$. indica dilakukan seperti cara yang sama. 
Sediaan diuji dengan metode pencelupan daun. Potongan daun brokoli $4 \mathrm{~cm} \mathrm{x} 4 \mathrm{~cm}$ dicelupkan dalam sediaan hingga permukaan daun terbasahi secara merata. Setelah kering udara, satu potong daun perlakuan diletakkan dalam cawan Petri (diameter $9 \mathrm{~cm}$ ) yang dialasi tisu. Selanjutnya ke dalam setiap cawan Petri dimasukkan 15 ekor larva instar II C. pavonana. Larva kontrol diberi makan daun yang hanya dicelup dalam pelarut sederhana. Setiap perlakuan diulang empat kali. Pemberian makan daun perlakuan dilakukan selama 2 x 24 jam. Pengamatan dilakukan terhadap mortalitas larva hingga awal instar IV. Pengujian disusun dalam rancangan acak lengkap. Data persentase mortalitas ditransformasi ke arcsin $\sqrt{ } \%$ kemudian dianalisis dengan sidik ragam. Pembandingan nilai tengah antarperlakuan dilakukan dengan uji selang berganda Duncan pada taraf nyata 5\% (Steel \& Torrie, 1993).

Aktivitas Penghambatan Peneluran. Percobaan bertujuan mengukur hambatan peneluran (antioviposisi) dari ekstrak biji $B$. asiatica terhadap peneluran oleh imago betina $C$. pavonana. Pengujian dilakukan pada bibit brokoli berumur 3-4 minggu setelah tanam (4 helai daun muda membuka sempurna). Ekstrak diuji pada konsentrasi subletal $0,14 \%, 1 \%$, dan $2 \%$ yang setara dengan $\mathrm{LC}_{50}, 3,5 \times \mathrm{LC}_{99}$, dan $7 \times \mathrm{LC}_{99}$. Sediaan disiapkan dengan akuades yang mengandung etanol dan pengemulsi/perekat/perata polioksietilen alkilarileter (Besmor, b.a. 207,4 $\mathrm{g} \mathrm{l}^{-1}$ ) masing-masing $1 \%$ dan 0,1\%. Pengujian dilakukan dengan metode pilihan seperti yang diuraikan Syahputra (2007). Percobaan diulang sebanyak enam kali. Jumlah kelompok telur yang diletakkan pada daun perlakuan dan kontrol dibandingkan menggunakan uji $t$-berpasangan $(\alpha=0,05)$. Hambatan peletakan peneluran (HPL) dihitung dengan rumus:

$$
\mathrm{HPL}=[(\mathrm{tk}-\mathrm{tp}) /(\mathrm{tk}+\mathrm{tp})] \times 100 \%
$$

tk $=\Sigma$ telur pada kontrol, tp $=\Sigma$ telur pada perlakuan, HPL akan sama $100 \%$ bila tp $=0$

Keefektifan Sediaan di Lapangan. Petak percobaan berukuran 2,2 $\mathrm{m} \times 1,7 \mathrm{~m}$ dengan jarak tanam dalam barisan $50 \mathrm{~cm}$ dan antarbarisan $70 \mathrm{~cm}$ (16 lubang tanam). Lahan disiapkan untuk percobaan yang disusun dalam rancangan acak kelompok dengan empat kelompok. Tanaman yang digunakan adalah kubis $\mathrm{F}_{1}$ King Cross untuk dataran rendah. Penanaman dan perawatan tanaman dilakukan menurut petunjuk penanaman kubis bagi petani setempat.
Berdasarkan hasil percobaan di atas, cara penyiapan sediaan yang dipilih untuk percobaan ini adalah sediaan sederhana berbahan serbuk biji B. asiatica pada konsentrasi $75 \mathrm{~g} \mathrm{l}^{-1}$ yang diblender 15 detik + direndam 1 jam dalam pelarut sederhana. Sebagai pembanding digunakan sediaan sederhana insektisida botani biji A. indica, kulit batang $B$. sarcostachys dan insektisida sintetik lamda-sihalotrin (Matador 25 EC; b.a. $25 \mathrm{~g} \mathrm{l}^{-1}$ ) dan kontrol. Konsentrasi insektisida sintetik yang digunakan adalah konsentrasi anjuran median yang terdapat pada label kemasan, yakni $1,5 \mathrm{ml} \mathrm{l}^{-1}$ setara dengan $37,5 \mathrm{mg}$ b.a. $\mathrm{l}^{-1}$. Perlakuan kontrol hanya menggunakan campuran air, etanol dan pengemulsi/perata/perekat polieoksietilen alkilarileter dengan konsentrasi akhir masing-masing $1 \%$ dan $0,1 \%$. Volume sediaan yang disemprotkan sebanyak $60 \mathrm{ml}$ per tanaman. Penyemprotan sediaan insektisida pada tanaman dilakukan dengan hand sprayer hingga seluruh permukaan tanaman basah merata.

Infestasi 30 ekor larva instar II C. pavonana (yang dibagi dalam 3 tanaman sampel) dan tiga pasang imago muda $C$. pavonana (4 hari setelah keluar dari kepompong) dilakukan pada setiap petak percobaan pada dua bulan setelah tanaman dipindahkan ke lapangan. Aplikasi sediaan insektisida perlakuan dilakukan pada 4 jam setelah infestasi hama di lapangan. Pengamatan dilakukan terhadap jumlah kelompok telur yang diletakkan imago betina $C$. pavonana dan populasi larvanya yang masih bertahan hidup. Pengamatan dilakukan setiap hari setelah aplikasi. Pengamatan jumlah kelompok telur yang diletakkan dilakukan pada keseluruhan tanaman dalam tiap petak percobaan, sedangkan pengamatan larva yang masih bertahan hidup dilakukan pada tiga tanaman sampel yang telah ditentukan saat sebelum infestasi hama. Data jumlah kelompok telur yang diletakkan untuk setiap percobaan selanjutnya dirata-ratakan \pm simpangan baku, selanjutnya ditentukan hambatan peletakan kelompok telur dengan rumus $(1-\mathrm{tp} / \mathrm{tk}) \times 100 \%$. Data populasi larva yang bertahan hidup ditransformasi ke arcsin $\sqrt{ } \%$, kemudian dianalisis dengan sidik ragam dan dilanjutkan dengan uji selang berganda Duncan pada taraf nyata 5\%.

\section{HASIL DAN PEMBAHASAN}

Aktivitas Insektisida. Ekstrak etanol biji B. asiatica pada kisaran konsentrasi $0,05-0,20 \%$ mengakibatkan mortalitas larva sekitar 9-87\% (Gambar 1). $\mathrm{LC}_{50}, \mathrm{LC}_{95}$, dan $\mathrm{LC}_{99}$ ekstrak tersebut masing-masing sebesar $0,14 \%, 0,24 \%$ dan $0,28 \%$ (Tabel 1). Kecilnya Nilai LC $_{50}$ tersebut $(<0,25 \%)$ menunjukkan bahwa aktivitas 
insektisida ekstrak tersebut kuat. Nilai $\mathrm{LC}_{50}$ ekstrak tersebut lebih kecil dibandingkan nilai $\mathrm{LC}_{50}$ ekstrak etanol kulit batang $B$. sarcostachys terhadap serangga yang sama, yakni sebesar $0,2 \%$. Hal ini berarti aktivitas ekstrak etanol biji $B$. asiatica lebih kuat dibandingkan ekstrak etanol kulit batang B. sarcostachys (Syahputra \& Prijono, 2003). Tingginya aktivitas sediaan ekstrak biji $B$. asiatica tidak terlepas dari peran senyawa aktif yang dikandungnya. Sampai saat ini senyawa aktif utama yang bersifat sebagai insektisida belum pernah dilaporkan. Dari tanaman yang sama dilaporkan bahwa senyawa saponin tanaman tersebut merupakan senyawa aktif utama yang dapat meracuni ikan (Cannon et al., 2004). Mengingat potensinya, penelitian lanjutan untuk mengembangkan ekstrak biji B. asiatica sebagai sumber insektisida botani perlu dilakukan.
Perkembangan mortalitas larva secara umum tinggi pada hari kedua setelah perlakuan dan tidak tampak pertambahan mortalitas yang mencolok pada hari-hari pengamatan berikutnya (Gambar 1). Pola perkembangan mortalitas larva menunjukkan bahwa komponen aktif yang terkandung pada ekstrak biji $B$. asiatica memiliki cara kerja yang relatif cepat dalam menimbulkan mortalitas larva. Contoh bahan aktif insektisida botani lain yang bekerja cepat dalam menimbulkan mortalitas larva seperti piretrin yang berasal dari tanaman piretrum (Asteraceae). Gejala keracunan yang teramati setelah larva mengonsumsi daun yang diberi perlakuan ekstrak etanol biji B. asiatica adalah larva kehilangan mobilitas dengan ukuran tubuh yang lebih kecil dibandingkan dengan tubuh larva kontrol. Larva yang mati berwarna hitam dengan kondisi kering.

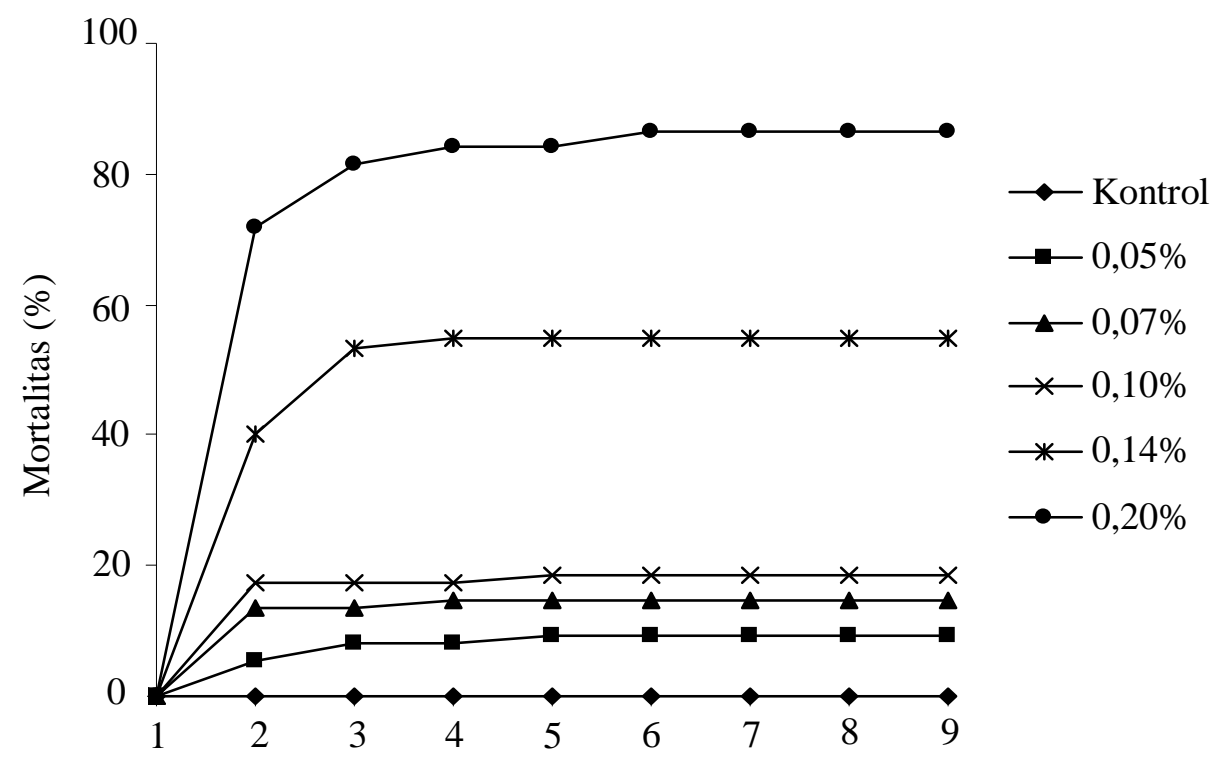

Hari setelah perlakuan

Gambar 1. Perkembangan mortalitas larva $C$. pavonana yang mengonsumsi daun brokoli yang diberi perlakuan sediaan ekstrak biji B. asiatica selama 48 jam pada berbagai konsentrasi dengan metode residu pada daun

Tabel 1. Parameter hubungan konsentrasi-mortalitas ekstrak etanol biji B. asiatica terhadap larva C. pavonana ${ }^{1}$

\begin{tabular}{ccccc}
\hline $\mathrm{a} \pm \mathrm{GB}$ & $\mathrm{b} \pm \mathrm{GB}$ & $\begin{array}{c}\mathrm{LC}_{50} \\
(\mathrm{SK} 95 \%)(\%)\end{array}$ & $\begin{array}{c}\mathrm{LC}_{95} \\
(\mathrm{SK} 95 \%)(\%)\end{array}$ & $\begin{array}{c}\mathrm{LC}_{99} \\
(\mathrm{SK} 95 \%)(\%)\end{array}$ \\
\hline$-2,24 \pm 0,26$ & $16,12 \pm 2,50$ & $0,14(0,13-0,16)$ & $0,24(0,20-0,31)$ & $0,28(0,24-0,37)$ \\
\hline
\end{tabular}

\footnotetext{
${ }^{1}$ Jumlah larva instar II yang diberi perlakuan 375 ekor dan kontrol 75 ekor. a = intersep garis regresi, $\mathrm{b}=$ kemiringan garis regresi, $\mathrm{GB}=$ galat baku, $\mathrm{SK}=$ selang kepercayaan .
} 
Pada larva yang mati tidak tampak adanya gejala gangguan yang terkait dengan fungsi sistem hormon perkembangan serangga karena tidak terjadi bentuk serangga yang menyimpang.

Sediaan sederhana berbahan serbuk biji B. asiatica dan A. indica pada konsentrasi dan cara penyiapan yang diuji seluruhnya menunjukkan aktivitas yang tinggi (Tabel 2). Semua perlakuan tersebut menyebabkan mortalitas larva C. pavonana $>90 \%$. Hal ini menunjukkan bahwa biji $B$. asiatica dapat disiapkan dengan cara seperti penyiapan sediaan biji A. indica dengan hasil yang serupa. Secara umum dapat dikatakan bahwa perlakuan sediaan sederhana berbahan serbuk biji tersebut aktif dalam menyebabkan mortalitas larva $C$. pavonana. Hal ini menunjukkan bahwa senyawa aktif yang terkandung dalam serbuk biji dapat terlarut/tersuspensikan di dalam sediaan sederhana.

Sediaan sederhana berbahan biji $B$. asiatica konsentrasi $50 \mathrm{~g} \mathrm{l}^{-1}$ yang disiapkan dengan cara perebusan 1 jam atau yang disiapkan dengan pemblenderan 15 detik dan perendaman 1 jam tidak berbeda nyata dalam menyebabkan kematian larva dibandingkan dengan konsentrasi $100 \mathrm{~g} \mathrm{l}^{-1}$. Karenanya, bila dikaitkan dengan keperluan penggunaan ekstrak di lapangan oleh petani, sediaan biji $B$. asiatica pada konsentrasi $50 \mathrm{gl}^{-1}$ menjadi pilihan. Syahputra \& Prijono (1999) melaporkan bahwa sediaan sederhana berbahan serbuk kulit batang Dysoxylum acutangulum yang disiapkan dengan pemblenderan dalam air pada konsentrasi $50 \mathrm{~g} \mathrm{l}^{-1}$ memiliki pengaruh letal 56\% terhadap larva $C$. pavonana, sedangkan pada konsentrasi $100 \mathrm{~g} \mathrm{l}^{-1}$, suspensi sediaan sederhana tersebut dapat menyebabkan kematian 100\%. Bahan dan konsentrasi yang sama yang disiapkan dengan perebusan selama 45 menit menyebabkan mortalitas larva $C$. pavonana sebesar $85,5 \%$.

Aktivitas Anti-oviposisi di Laboratorium. Perlakuan ekstrak etanol biji $B$. asiatica pada konsentrasi $0,14 \%, 1 \%$, dan $2 \%$ pada bibit tanaman brokoli tidak menunjukkan perbedaan jumlah kelompok telur yang diletakkan imago betina C. pavonana, tetapi secara nyata dapat menurunkan jumlah telur yang diletakkan dibandingkan dengan kontrol (Tabel 3). Perbedaan hasil antara jumlah kelompok telur dan jumlah telur yang diletakkan dikarenakan tidak konsistennya jumlah telur pada tiap-tiap kelompok telur yang menyebabkan variasi data cukup tinggi. Jumlah kelompok telur yang banyak tidak selalu menunjukkan jumlah telur yang banyak. Keadaan ini terjadi pada tiap perlakuan maupun kontrol. Selanjutnya pembahasan pada percobaan ini difokuskan pada jumlah telur, bukan kelompok telur.

Pada setiap perlakuan yang diuji, jumlah telur yang diletakkan oleh imago betina bervariasi, dengan kecenderungan peningkatan konsentrasi ekstrak diikuti dengan peningkatan penurunan jumlah telur yang diletakkan. Perlakuan ekstrak pada konsentrasi yang

Tabel 2. Pengaruh sediaan sederhana biji B. asiatica dan biji A. indica terhadap mortalitas larva C. pavonana

\begin{tabular}{|c|c|c|c|}
\hline Bahan & $\begin{array}{l}\text { Konsentrasi } \\
\qquad\left(\mathrm{g} \mathrm{l}^{-1}\right)^{1}\end{array}$ & Cara penyiapan sediaan & Rataan mortalitas $(\%)^{2}$ \\
\hline & Kontrol & & $0 \quad \mathrm{c}$ \\
\hline \multicolumn{4}{|c|}{ Biji B. asiatica } \\
\hline & 50 & Rebus 1 jam & $97,1 \quad \mathrm{a}$ \\
\hline & 50 & Blender 15 detik rendam 1 jam & $100 \mathrm{a}$ \\
\hline & 100 & Blender 15 detik rendam 1 jam & $100 \mathrm{a}$ \\
\hline \multicolumn{4}{|l|}{ Biji A. indica } \\
\hline & 50 & Rebus 1 jam & $100 \mathrm{a}$ \\
\hline & 50 & Blender 15 detik rendam 1 jam & $90,5 \quad b$ \\
\hline & 100 & Blender 15 detik rendam 1 jam & $98,2 \quad \mathrm{a}$ \\
\hline
\end{tabular}

${ }^{1}$ Jumlah larva uji yang digunakan berkisar $66-77$ ekor.

${ }^{2}$ Sidik ragam dilakukan setelah data ditransformasi ke arcsin $\sqrt{ } \%$. Rataan selajur yang diikuti oleh huruf yang sama tidak berbeda nyata (uji Duncan, $\alpha=0,05$ ). 
diuji menurunkan jumlah telur yang diletakkan pada bibit tanaman brokoli yang diberi perlakuan 2-22 kali dibandingkan dengan kontrol. Persentase hambatan peletakan telur dari perlakuan ekstrak pada konsentrasi yang diuji menunjukkan nilai yang tinggi pula yakni berkisar dari 48,9\% sampai 91,6\%.

Beberapa sediaan dan senyawa aktif dari tumbuhan dapat menurunkan aktivitas peneluran berbagai imago serangga. Prijono \& Hassan (1993) melaporkan bahwa ekstrak A. indica (Meliaceae) pada konsentrasi $0,4 \%$ secara nyata menurunkan jumlah telur imago C. pavonana yang diletakkan pada bibit tanaman brokoli. Emulsi minyak tanaman tersebut dapat mengurangi jumlah telur yang diletakkan Spodoptera litura (Naumann \& Isman, 1995). Toosendanin dan azadiraktin yang masing-masing diisolasi dari Melia toosendan dan A. indica juga memiliki aktivitas penghambatan peletakan telur pada berbagai serangga (Chiu, 1985; Isman et al., 1995).

\section{Keefektifan di Lapangan}

Jumlah telur yang diletakkan. Perlakuan sediaan sederhana berbahan serbuk biji $B$. asiatica, kulit batang $B$. sarcostachys, dan biji $A$. indica pada konsentrasi $75 \mathrm{~g} \mathrm{l}^{-1}$ yang disemprotkan pada tanaman kubis di lapangan dapat menghambat peletakan telur oleh imago betina $C$. pavonana hingga $100 \%$ dibandingkan dengan kontrol. Hasil yang sama juga diperoleh pada perlakuan dengan insektisida pembanding lamda-sihalotrin
$37,5 \mathrm{mg} \mathrm{l}^{-1}$. Pada kontrol, jumlah kelompok telur yang diletakkan rata-rata 1,8 ( \pm 1$)$ kelompok, sedangkan pada perlakuan dengan ketiga jenis sediaan sederhana yang diuji dan insektisida lamda-sihalotrin tidak ditemukan adanya telur $C$. pavonana (data terperinci tidak ditunjukkan).

Serangga Lepidoptera dewasa dalam menemukan inang untuk peletakan telur dipandu oleh senyawa-senyawa sekunder yang dikeluarkan oleh tanaman. Keberadaan senyawa penarik ataupun penolak akan menentukan apakah tumbuhan tersebut dapat dijadikan inang atau tidak. Serangga akan meletakkan telur pada inang jika terdapat senyawa kimia tertentu, sebaliknya tidak akan meletakkan telur jika tidak ditemukan senyawa kimia yang sesuai atau karena keberadaan senyawa-senyawa lain. Adanya hambatan peletakan telur oleh imago betina $C$. pavonana pada bibit brokoli yang diberi perlakuan sediaan ekstrak niji B. asiatica pada percobaan ini kemungkinan disebabkan sediaan tersebut mengandung senyawa asing yang bersifat sebagai penolak, dan atau dapat juga disebabkan karena tertutupnya sinyal penarik yang terdapat pada tanaman oleh sinyal-sinyal senyawa yang terkandung di dalam sediaan uji. Alilisotiosianat merupakan senyawa yang berperan dalam menarik imago betina C. pavonana untuk meletakkan telur. Tertariknya serangga betina untuk meletakkan telur merupakan gabungan dari respons terhadap rangsangan yang diterima indera penglihatan, mekanis, olfaktori, dan

Tabel 3. Pengaruh sediaan ekstrak biji B. asiatica terhadap penghambatan peletakan telur imago betina C. pavonana dengan metode pilihan di laboratorium ${ }^{1}$

\begin{tabular}{|c|c|c|c|c|c|}
\hline \multirow{2}{*}{$\begin{array}{l}\text { Konsentrasi (\%) } \\
\quad(\text { setara LC) }\end{array}$} & \multicolumn{2}{|c|}{$\begin{array}{c}\text { Rataan jumlah kelompok } \\
\text { telur yang diletakkan (butir) } \\
\pm \mathrm{SB}^{2}\end{array}$} & \multicolumn{2}{|c|}{$\begin{array}{l}\text { Rataan jumlah telur yang diletakkan } \\
\text { (butir) } \pm \mathrm{SB}^{2}\end{array}$} & \multirow{2}{*}{$\begin{array}{r}\mathrm{HPL}^{3} \\
(\%)\end{array}$} \\
\hline & Perlakuan & Kontrol & Perlakuan & Kontrol & \\
\hline $0,14\left(\mathrm{LC}_{50}\right)$ & $11 \pm 5,7 \mathrm{a}$ & $7,7 \pm 5,5 \mathrm{a}$ & $119,2 \pm 95,9 a$ & $347,8 \pm 197,7 \mathrm{~b}$ & 48,9 \\
\hline $1\left(3,5 x^{\prime} C_{99}\right)$ & $5 \pm 6,2 \mathrm{a}$ & $11 \pm 7,2 \mathrm{a}$ & $51,2 \pm 62,3 \mathrm{a}$ & $482,5 \pm 170,9 b$ & 80,8 \\
\hline $2\left(7 \times L_{99}\right)$ & $7,2 \pm 3,9 \mathrm{a}$ & $13,2 \pm 5,2 \mathrm{a}$ & $21,2 \pm 39,7 \mathrm{a}$ & $481,7 \pm 97,7 b$ & 91,6 \\
\hline
\end{tabular}

${ }^{1}$ Jumlah imago yang digunakan untuk setiap konsentrasi 18 pasang. ${ }^{2} \mathrm{SB}:$ simpangan baku. ${ }^{3} \mathrm{HPL}=$ hambatan peletakan telur yang dihitung dengan rumus $=(\mathrm{tk}-\mathrm{tp}) /(\mathrm{tk}+\mathrm{tp})] \mathrm{x} 100 \%$. Untuk setiap konsentrasi setiap sediaan pada setiap rataan jumlah kelompok telur atau jumlah telur, rataan yang diikuti oleh huruf yang sama tidak berbeda nyata menurut uji $t$ berpasangan $(\alpha=5 \%)$. 
gustatori (Honda, 1995). Indera olfaktori serangga mendeteksi komponen senyawa volatil dari sediaan sedangkan indera mekanis dan gustatori mendeteksi komponen senyawa nonvolatil yang melekat pada daun. Pemilihan inang oleh imago serangga betina untuk peletakan telur dipandu oleh kemoreseptor yang terletak di antena, tarsus, ovipositor atau probosisnya (Qiu et al., 1998).

Populasi larva. Perlakuan dengan sediaan sederhana biji $B$. asiatica, kulit batang $B$. sarcostachys, dan biji $A$. indica, masing-masing pada konsentrasi $75 \mathrm{~g} \mathrm{l}^{-1}$, serta formulasi lamda-sihalotrin $37,5 \mathrm{mg} \mathrm{l}^{-1}$ menekan populasi larva $C$. pavonana sampai 0\% (larva yang bertahan hidup 0\%) baik pada 1 maupun 2 hari setelah aplikasi. Pada kontrol, semua larva yang diinfestasi masih dapat ditemukan pada tanaman percobaan (larva yang bertahan hidup 100\%). Dengan demikian, ketiga jenis sediaan sederhana yang diuji dan insektisida pembanding lamda-sihalotrin memiliki tingkat efikasi $100 \%$. Hasil percobaan lapangan ini perlu diverifikasi dengan menggunakan serangga pada kondisi infestasi alami.

\section{SIMPULAN}

Ekstrak etanol biji $B$. asiatica memiliki aktivitas insektisida dan aktivitas penghambatan peneluran terhadap serangga $C$. pavonana. Pemblenderan selama 15 detik dan perendaman 1 jam serbuk biji $B$. asiatica pada konsentrasi $50 \mathrm{~g} \mathrm{l}^{-1}$ merupakan cara penyiapan sediaan sederhana yang paling baik. Penyemprotan sediaan sederhana berbahan serbuk biji B. asiatica pada konsentrasi $75 \mathrm{~g} \mathrm{l}^{-1}$ pada tanaman kubis di lapangan efektif menekan populasi larva $C$. pavonana.

\section{DAFTAR PUSTAKA}

Cannon JG, Burton RA, Wood SG \& Owen NL. 2004. Naturally occurring fish poisons from plants. $J$. Chem. Edu. 81(10): 1457-1461.

Chiu SF. 1985. Recent research finding on Meliaceae and other promising botanical insecticides in China. Z. Pflkrankh. Pflsch. 92: 310-319.

Dono D \& Prijono D. 1998. Aktivitas insektisida ekstrak biji Aglaia harmsiana Perkins dan fraksinya terhadap larva Crocidolomia binotalis Zeller (Lepidoptera: Pyralidae). Bul. HPT. 10: $19-28$
Grainge M \& Ahmed S. 1988. Handbook of Plants with Pest-Control Properties. John Wiley \& Sons, New York.

Honda K. 1995. Chemical basis of differential oviposition by Lepidopterous insects. Arch. Insect Biochem. Physiol. (30): 1-23.

Isman MB, Arnason JT \& Towers GHN. 1995. Chemistry and biological activity of ingredients of other species of Meliaceae. Pp. 652-666 In: Schmutterer, eds. The Neem Tree: Source of Unique Natural Products for Integrated Pest Management, Medicine, Industry and Other Purposes. VCH, Weinheim.

Naumann K \& Isman MB. 1995. Evaluation of neem Azadirachta indica seed axtract and oil as oviposition deterrents to noctuid moths. Entomol. Exp. Appl. 76: 115-120.

Prijono D \& Hassan E. 1993. Effects of neem (Azadirachta indica A. Jussieu) extract on feeding, development, reproduction, longevity and oviposition of Crocidolomia binotalis Zeller (Lepidoptera: Pyralidae). Bul. HPT. 6(2): 55-65.

Qiu YT, van Loon JJA \& Roessingh P. 1998. Chemoreception of oviposition inhibiting terpenoids in the diamondback moth Plutella xylostella. Entomol. Exp. Appl. 87: 143-155.

Rauf A, Prijono D, Dadang, Winasa IW \& Russel DA. 2005. Survey on pesticide use by cabbage farmers in West Java, Indonesia. Report of Research Collaboration between Departement. of Plant Protection-IPB and LaTrobe University, Australia.

SAS. Institute. 1990. SAS/STAT User's Guide, Version 6. Fourth Edition, Volume 2. SAS Institute Inc, Raleigh (North Carolina).

Schmutterer H. 1997. Side-effects of neem (Azadirachta indica) products on insect pathogens and natural enemies of spider mites and insects. J. Appl. Entomol. 121: 121-128. 
Steel RGD \& Torrie JH. 1993. Prinsip dan Prosedur Statistika: Suatu Pendekatan Biometrika. Sumantri B, Alih bahasa. PT Gramedia Pustaka Utama, Jakarta.

Syahputra E, Rianto F \& Prijono D. 2001. Aktivitas insektisida ekstrak tumbuhan asal Kalimantan Barat terhadap kumbang kacang Callosobruchus maculatus (F.) dan ulat kubis Crocidolomia binotalis Zeller. J. Ilmu Pert. Indon. 10(1): 8-13.

Syahputra E \& Prijono D. 2003. Aktivitas insektisida ekstrak kulit batang Calophyllum soulattri (Clusiaceae) dan Barringtonia sarcostachys (Lecythidaceae) terhadap ulat krop kubis
Crocidolomia pavonana. Makalah disajikan pada Semiloka Jeruk Nasional dan Seminar Hasil Riset Bidang Pertanian, Pontianak, 9-12 Juni 2003.

Syahputra E, Prijono D, Manuwoto S, Darusman LK \& Dadang. 2004. Aktivitas insektisida ekstrak kulit batang empat famili tumbuhan terhadap ulat krop kubis Crocidolomia pavonana (F.) J. Perlin. Tan. Indon. 10(1): 13-22.

Syahputra E. 2007. Sediaan insektisida Calophyllum soulattri: Aktivitas terhadap reproduksi dan oviposisi Crocidolomia pavonana. J. Agrikultura 18: 105-110. 